\title{
Synthesis and Chemosensory Behavior of Anthracene Bisimide Derivatives
}

Faysal Ilhan, Daniel S. Tyson, and Michael A. Meador

\author{
Polymers Branch, Materials Division \\ NASA Glenn Research Center, \\ 21000 Brookpark Road, \\ Cleveland, Ohio 44135,

$$
\text { And }
$$ \\ Ohio Aerospace Institute, \\ 22800 Cedar Point Road, \\ Cleveland, Ohio 44142
}




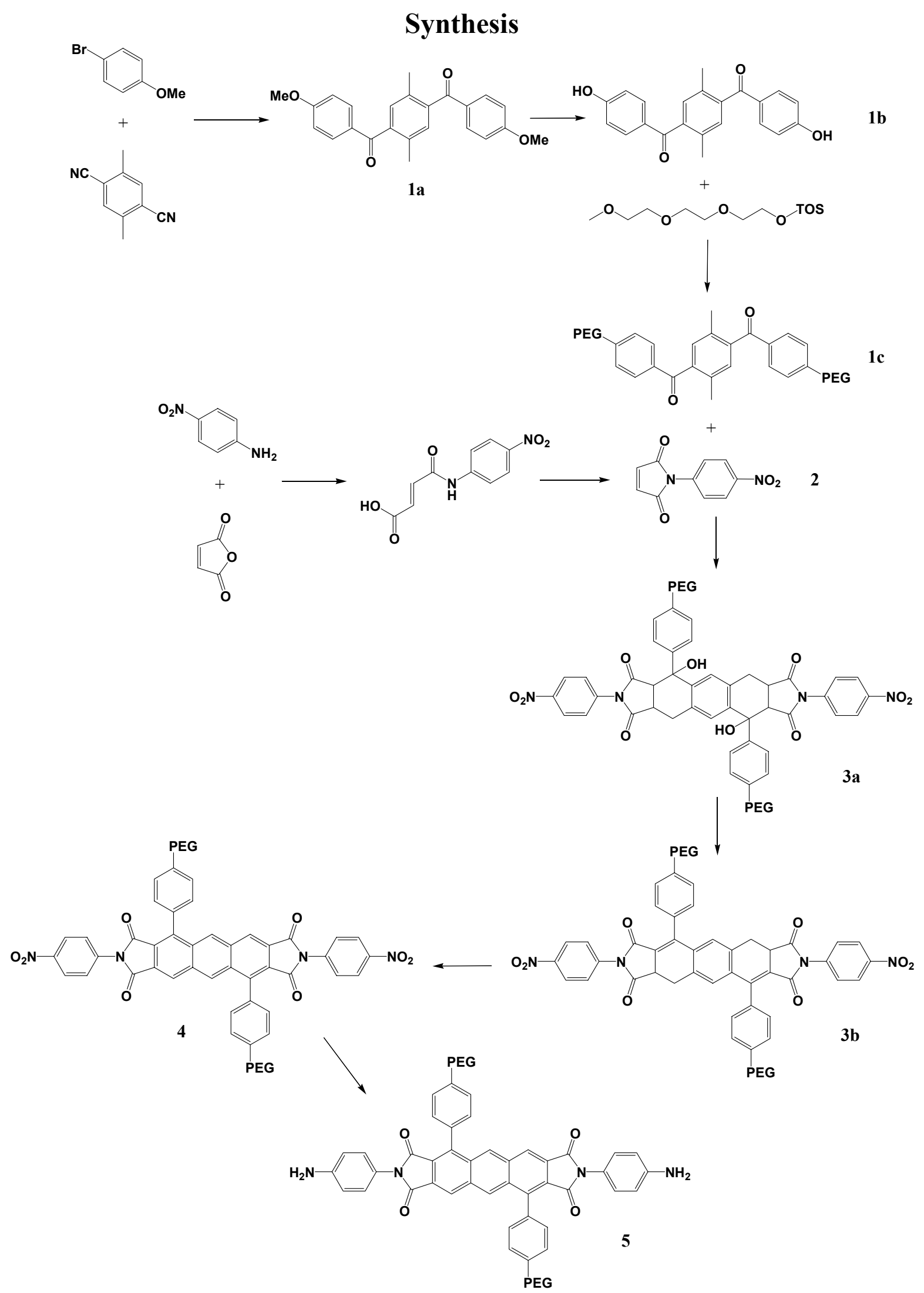

Supporting Scheme 1. Total synthesis of $\mathrm{ABI}-\mathrm{NH}_{2}$ (5). 
Materials. 2,5-dimethyl-1,4-dicyanobenzene was custom synthesized by Aldrich. Triethylene glycol monomethyl ether, p-toluene sulfonyl chloride, $\mathrm{Mg}$ turnings and all the solvents were purchased from Aldrich. $\mathrm{N}$-(p-nitrophenyl) maleimide ${ }^{1 \mathrm{a}}$ and triethylene glycol monomethyl ether tosylate (PEG-TsCl) ${ }^{1 \mathrm{~b}}$ were prepared according to literature procedures. Reagent grade tetrahydrofuran was dried over sodium/benzophenone prior to use. All ${ }^{1} \mathrm{H}$ NMR and ${ }^{13} \mathrm{C}$ NMR spectra $\left(200 \mathrm{MHz}\right.$ or $400 \mathrm{MHz}$ ) were recorded using $\mathrm{CDCl}_{3}$ or $\mathrm{d}_{6}$-DMSO as solvent. IR spectra were recorded in $\mathrm{KBr}$ pellets using a Nicolet 510P FTIR spectrophotometer. Mass data was measured on a Finnegan LCQ (atmospheric pressure ionization) in positive ion mode with an inlet temperature of $180^{\circ} \mathrm{C}$.

2,5-bis(p-(methoxy)benzoyl)-p-xylene (1a). To a $500 \mathrm{ml} \mathrm{3-neck} \mathrm{round} \mathrm{bottom} \mathrm{flask} \mathrm{fitted} \mathrm{with}$ an addition funnel and a reflux condenser, magnesium turnings (4 g, $0.17 \mathrm{~mol}$ ) and freshly distilled THF (50 ml) were added. To this mixture, 4-bromoanisole $(21.7 \mathrm{~g}, 0.116 \mathrm{~mol})$ was added dropwise. The reaction mixture was refluxed for $2 \mathrm{hrs,} \mathrm{cooled} \mathrm{to} \mathrm{room} \mathrm{temperature,} \mathrm{and}$ transferred to the addition funnel. The unreacted portion of $\mathrm{Mg}$ turnings was kept in the round bottom flask. To the same round bottom flask, 2,5-dimethyl-1,4-dicyanobenzene (8 g, $0.051 \mathrm{~mol})$ and $200 \mathrm{ml}$ freshly distilled THF were added. To this mixture, the solution of $p$ methoxybenzenelmagnesium bromide in the addition funnel was added dropwise at room temperature. The resulting mixture was refluxed under nitrogen for $18 \mathrm{hrs}$. The reaction mixture was then cooled to room temperature and added into $300 \mathrm{ml}$ of a saturated aqueous solution of ammonium chloride. The two phases were separated and the aqueous phase was extracted twice with $150 \mathrm{ml}$ portions of THF. Combined organic layers were dried over $\mathrm{Na}_{2} \mathrm{SO}_{4}$ and evaporated to dryness in vacuo to yield a brown oily product. This oil was then dissolved in a solution of $125 \mathrm{ml}$ concentrated $\mathrm{HCl}$ in $125 \mathrm{ml}$ of distilled $\mathrm{H}_{2} \mathrm{O}$ and refluxed for $18 \mathrm{hrs}$ under nitrogen. The resulting mixture was cooled to room temperature and extracted three times with $150 \mathrm{ml}$ portions of $\mathrm{CH}_{2} \mathrm{Cl}_{2}$. Combined organic layers were washed twice with $200 \mathrm{ml}$ portions of a solution of $\mathrm{NaOH}\left(5 \%\right.$, aq.). The organic layer was dried over $\mathrm{Na}_{2} \mathrm{SO}_{4}$ and evaporated to dryness in vacuo to provide a dark cream colored solid as the crude product. This was then recrystallized from ethanol and filtered to collect cream colored crystalline product in $63 \%$ yield $(12.02 \mathrm{~g})$. ${ }^{1} \mathrm{H} \mathrm{NMR}$ $\left(200 \mathrm{MHz}, \mathrm{CDCl}_{3}\right): \delta 2.24(\mathrm{~s}, 6 \mathrm{H}), 3.88(\mathrm{~s}, 6 \mathrm{H}), 6.92(\mathrm{~d}, J=8 \mathrm{~Hz}, 4 \mathrm{H}), 7.16(\mathrm{~s}, 2 \mathrm{H}), 7.79(\mathrm{~d}, J=$ $8 \mathrm{~Hz}, 2 \mathrm{H})$. 
2,5-bis(p-(hydroxyl)benzoyl)-p-xylene (1b). To a $250 \mathrm{ml}$ round bottom flask, 1a (6.5 g, 17.4 $\mathrm{mmol}), 48 \% \mathrm{HBr}$ in $\mathrm{H}_{2} \mathrm{O}(100 \mathrm{ml})$ and $50 \mathrm{ml}$ acetic acid were added. The mixture was refluxed for $18 \mathrm{hrs}$ then allowed to cool to room temperature. It was then added into $200 \mathrm{ml}$ of cold $\mathrm{H}_{2} \mathrm{O}$. This mixture was filtered to collect the cream colored solid product. This was then recrystallized from $\mathrm{CH}_{3} \mathrm{OH}$ with a yield of $77 \%(4.59 \mathrm{~g}) .{ }^{1} \mathrm{H}$ NMR (200 MHz, $\left.\mathrm{d}_{6}-\mathrm{DMSO}\right): \delta 2.16(\mathrm{~s}, 6 \mathrm{H}), 6.89$ (d, $J=8 \mathrm{~Hz}, 4 \mathrm{H}), 7.21$ (s, 2H), 7.65 (d, $J=8 \mathrm{~Hz}, 2 \mathrm{H}), 10.59$ (broad s, 2H).

2,5-bis(p-(tetraethyleneglycoloxy)benzoyl)-p-xylene (1c). To a $200 \mathrm{ml}$ round bottom flask, $1 \mathbf{b}$ (3 g, $8.67 \mathrm{mmol}), \mathrm{K}_{2} \mathrm{CO}_{3}(3.6 \mathrm{~g}, 26 \mathrm{mmol})$ and DMF $(30 \mathrm{ml})$ were added. The mixture was stirred at $55{ }^{\circ} \mathrm{C}$ for $1 / 2 \mathrm{hrs}$ under $\mathrm{N}_{2}$ and a solution PEG-TsCl $(5.8 \mathrm{~g}, 18.2 \mathrm{mmol})$ in $10 \mathrm{ml}$ of DMF was added dropwise. The resulting mixture was stirred at $75^{\circ} \mathrm{C}$ for $18 \mathrm{hrs}$ and then cooled to room temperature. The solvent was evaporated in vacuo and $150 \mathrm{ml}$ of diethyl ether was added to the resulting crude product. This was then extracted with $\mathrm{H}_{2} \mathrm{O}(2 \times 30 \mathrm{ml}), 5 \%$ solution of aqueous $\mathrm{NaOH}(2 \times 30 \mathrm{ml})$, and brine $(2 \times 30 \mathrm{ml})$ and finally dried over $\mathrm{Na}_{2} \mathrm{SO}_{4}$. Concentration in vacuo yielded yellow oil that solidified gradually to form a cream colored solid product (4.77 g, 86\% yield). ${ }^{1} \mathrm{H}$ NMR (200 MHz, $\left.\mathrm{CDCl}_{3}\right): \delta 2.24(\mathrm{~s}, 6 \mathrm{H}), 3.38(\mathrm{~s}, 6 \mathrm{H}), 3.50-3.73(\mathrm{~m}, 16 \mathrm{H})$, $3.89(\mathrm{t}, J=2 \mathrm{~Hz}, 4 \mathrm{H}), 4.21(\mathrm{t}, J=2 \mathrm{~Hz}, 4 \mathrm{H}), 6.94(\mathrm{~d}, J=10 \mathrm{~Hz}, 4 \mathrm{H}), 7.17(\mathrm{~s}, 2 \mathrm{H}), 7.78(\mathrm{~d}, J=$ $10 \mathrm{~Hz}, 4 \mathrm{H})$.

\section{N,N'-Bis(p-nitrophenyl)-1,5-dihydroxy-1,5-bis(p-(tetraethyleneglycoloxy)phenyl)-1,2,3,4,5,}

6,7,8-octahydro-anthracene-2,3,6,7-tetracarboxyl bisimide (3a). A $330 \mathrm{ml}$ of benzene solution of $1 \mathrm{c}$ ( $2 \mathrm{~g}, 3.14 \mathrm{mmol})$ and $\mathrm{N}$-(p-nitrophenyl) maleimide, $2{ }^{1}{ }^{1}(1.44 \mathrm{~g}, 6.6 \mathrm{mmol})$ was vigorously degassed with a stream of nitrogen for $45 \mathrm{~min}$. The stirred solution was then irradiated under nitrogen for $18 \mathrm{hrs}$ using a $450 \mathrm{~W}$ medium pressure $\mathrm{Hg}$ lamp (Hanovia) equipped with a Pyrex filter. The benzene was removed under vacuum, triturated with $50 \mathrm{ml}$ of methanol and filtered to collect a cream colored solid product as a mixture of two possible stereoisomers (3.31 g, 98\% yield). This product was used without any further purification. ${ }^{1} \mathrm{H}$ NMR (200 MHz, $\left.\mathrm{CDCl}_{3}\right): \delta 2.85-3.05(\mathrm{~m}, 4 \mathrm{H}), 3.35(\mathrm{~s}, 6 \mathrm{H}), 3.40-3.75(\mathrm{~m}, 20 \mathrm{H}), 3.85(\mathrm{t}, J=2$ $\mathrm{Hz}, 4 \mathrm{H}), 4.15$ (t, $J=2 \mathrm{~Hz}, 4 \mathrm{H}), 6.13(\mathrm{~s}, 2 \mathrm{H}), 6.69$ (s, 2H), 6.95 (d, J=8 Hz, 4H), 7.28 (d, J=8 $\mathrm{Hz}, 4 \mathrm{H}), 7.41$ (d, $J=8 \mathrm{~Hz}, 4 \mathrm{H}), 8.33$ (d, J = $8 \mathrm{~Hz}, 4 \mathrm{H})$. 
N,N'-Bis(p-nitrophenyl)-1,5-bis(p-(tetraethyleneglycoloxy)phenyl)-2,3,4,6,7,8-hexahydroanthracene-2,3,6,7-tetracarboxyl bisimide (3b). A solution of 3a $(2.7 \mathrm{~g}, 2.51 \mathrm{mmol})$ and catalytic amount of p-toluene sulfonic acid monohydrate $(0.3 \mathrm{~g}, 1.57 \mathrm{mmol})$ in $250 \mathrm{ml}$ of toluene was refluxed under nitrogen for $18 \mathrm{hrs}$. The resulting solution was allowed to cool to room temperature. Then it was washed twice with $50 \mathrm{ml}$ portions of a solution of $\mathrm{NaOH}(5 \%$, aq.) and once with $30 \mathrm{ml}$ of distilled $\mathrm{H}_{2} \mathrm{O}$. The organic layer was dried over $\mathrm{Na}_{2} \mathrm{SO}_{4}$ and evaporated to dryness in vacuo to afford a dark yellow solid product in $58 \%$ yield $(1.5 \mathrm{~g}) .{ }^{1} \mathrm{H}$ NMR $(200 \mathrm{MHz}$, $\left.\mathrm{CDCl}_{3}\right): \delta 2.85-3.05(\mathrm{~m}, 4 \mathrm{H}), 3.37(\mathrm{~s}, 6 \mathrm{H}), 3.60-3.75(\mathrm{~m}, 18 \mathrm{H}), 3.85(\mathrm{t}, J=2 \mathrm{~Hz}, 4 \mathrm{H}), 4.15(\mathrm{t}, J$ $=2 \mathrm{~Hz}, 4 \mathrm{H}), 6.92-7.40(\mathrm{~m}, 10 \mathrm{H}), 7.64(\mathrm{~d}, J=10 \mathrm{~Hz}, 4 \mathrm{H}), 8.26(\mathrm{~d}, \mathrm{~J}=10 \mathrm{~Hz}, 4 \mathrm{H})$.

\section{N,N'-Bis(p-nitrophenyl)-1,5-bis(p-(tetraethyleneglycoloxy)phenyl)anthracene-2,3,6,7-}

tetracarboxyl bisimide (4). A solution of $\mathbf{3 b}$ (1.7 g, $1.64 \mathrm{mmol})$ and DDQ (2,3-dichloro-5,6dicyano-1,4-benzoquinone) ( $0.75 \mathrm{~g}, 3.3 \mathrm{mmol})$ in $130 \mathrm{ml}$ of chlorobenzene was refluxed under nitrogen for $18 \mathrm{hrs}$. The resulting mixture was allowed to cool to room temperature. Then it was washed three times with $50 \mathrm{ml}$ portions of a solution of $\mathrm{NaOH}(5 \%$, aq.) and once with $50 \mathrm{ml}$ of distilled $\mathrm{H}_{2} \mathrm{O}$. The organic layer was dried over $\mathrm{Na}_{2} \mathrm{SO}_{4}$ and evaporated to dryness in vacuo to dryness to yield a dark yellow colored solid product (1.0 g, 60\%). ${ }^{1} \mathrm{H}$ NMR (400 $\left.\mathrm{MHz}, \mathrm{CDCl}_{3}\right)$ : $\delta 3.52(\mathrm{~s}, 6 \mathrm{H}), 3.63-3.76(\mathrm{~m}, 16 \mathrm{H}), 3.90(\mathrm{t}, J=4 \mathrm{~Hz}, 4 \mathrm{H}), 4.22(\mathrm{t}, J=4 \mathrm{~Hz}, 4 \mathrm{H}), 7.12$ (d, $J=8$ $\mathrm{Hz}, 4 \mathrm{H}), 7.39$ (d, $J=8 \mathrm{~Hz}, 4 \mathrm{H}), 7.71$ (d, $J=8 \mathrm{~Hz}, 4 \mathrm{H}), 8.26$ (d, $J=8 \mathrm{~Hz}, 4 \mathrm{H}), 8.56$ (s, 2H), 8.71 (s, 2H). ${ }^{13} \mathrm{C}$ NMR $\left(400 \mathrm{MHz}, \mathrm{CDCl}_{3}\right): \delta 59.07,67.57,69.68,70.63,70.73,70.90,71.95,114.74$, $123.19,124.23,125.20,126.61,127.56,131.28,132.57,134.28,134.95,137.46,142.57,146.51$, 159.80, 164.97, 165.18. IR $\left(\mathrm{cm}^{-1}\right): 2872.4,1762.2,1722.8,1609.0,1595.4,1523.0,1511.3$, 1496.2, 1380.3, 1345.0, 1255.8, 1204.0, 1178.1, 1121.2, 1099.5. Calculated for $\mathrm{C}_{56} \mathrm{H}_{50} \mathrm{~N}_{4} \mathrm{O}_{16} \cdot \mathrm{H}_{2} \mathrm{O}: \mathrm{C}$ 63.82, H 4.98, N 5.32. Found: C 63.78, H 4.84, N 5.31.

\section{N,N'-Bis(p-aminophenyl)-1,5-bis(p-(tetraethyleneglycoloxy)phenyl)anthracene-2,3,6,7-}

tetracarboxyl bisimide (5). To a $50 \mathrm{ml}$ round bottom flask, $4(0.7 \mathrm{~g}, 0.68 \mathrm{mmol})$ and $5 \mathrm{ml}$ of DMF were added. This mixture was then sonicated to obtain a heterogeneous solution. Triethyl amine $(1 \mathrm{ml})$ and $5 \mathrm{wt}$. \% palladium on activated carbon $(0.095 \mathrm{~g})$ were added to the same flask and the resulting mixture was cooled to $0{ }^{\circ} \mathrm{C}$ in an ice bath. A solution of formic acid $(0.26 \mathrm{~g})$ in 
$2 \mathrm{ml}$ of DMF was added dropwise over a period of 15 minutes. After the addition was complete, the resulting mixture was stirred at $70{ }^{\circ} \mathrm{C}$ for $2 \mathrm{hrs}$. DMF was dried under vacuum and $50 \mathrm{ml}$ of $\mathrm{CH}_{2} \mathrm{Cl}_{2}$ was added to the resulting crude product to dissolve any organic impurities. The mixture was filtered over a 3 micron pore size filter and the filtrate was discarded. The solid portion was washed with DMF $(2 \times 50 \mathrm{ml})$ and the filtrate was dried under vacuum to yield the dark yellow colored solid product (0.58 g, 88\%). ${ }^{1} \mathrm{H}$ NMR (400 MHz, DMSO): $\delta 3.20-3.67$ (m, 22H), 3.85 $(\mathrm{t}, J=4 \mathrm{~Hz}, 4 \mathrm{H}), 4.26(\mathrm{t}, J=4 \mathrm{~Hz}, 4 \mathrm{H}), 5.24(\operatorname{broad~s}, 4 \mathrm{H}), 6.62(\mathrm{~d}, J=8 \mathrm{~Hz}, 4 \mathrm{H}), 7.00(\mathrm{~d}, J=8$ $\mathrm{Hz}, 4 \mathrm{H}), 7.16(\mathrm{~d}, J=8 \mathrm{~Hz}, 4 \mathrm{H}), 7.48(\mathrm{~d}, J=8 \mathrm{~Hz}, 4 \mathrm{H}), 8.71(\mathrm{~s}, 2 \mathrm{H}), 8.80(\mathrm{~s}, 2 \mathrm{H}) .{ }^{13} \mathrm{C}$ NMR $(400$ MHz, DMSO): $\delta$ 58.04, 67.24, 68.98, 69.62, 69.83, 69.97, 71.27, 113.31, 114.08, 119.81, 123.91, 125.24, 125.64, 127.94, 128.13, 131.40, 131.74, 133.67, 139.71, 148.70, 158.76, 165.92, 166.20. Mass spec (m/z): 975.0 calculated, 975.8 found. IR $\left(\mathrm{cm}^{-1}\right): 3461.6,3374.3,2870.7$, $1760.7,1720.0,1608.0,1515.8,1384.7,1357.2,1289.4,1248.5,1203.0,1177.3,1109.9$. Calculated for $\mathrm{C}_{56} \mathrm{H}_{54} \mathrm{~N}_{4} \mathrm{O}_{12} \bullet \mathrm{H}_{2} \mathrm{O}$ : C 67.73, H 5.68, N 5.64. Found: C 67.67, H 5.33, N 5.71. 


\section{Photophysical}

Analytically pure samples of $\mathrm{ABI}-\mathrm{NO}_{2}$ and $\mathrm{ABI}-\mathrm{NH}_{2}$ were used for all experiments. Purification was achieved using revered phase HPLC via a Waters 2690 HPLC system (Alliance series) equipped with a Waters 996 photodiode array (PDA) detector or a Beckman Gold 126 HPLC system (Rheodyne 7725 injector) equipped with a dual channel UV-vis detector (Waters 2487). A detection wavelength of $425 \mathrm{~nm}$ provided adequate sensitivity for all samples. A Hamilton PRP-1 column (analytical or semi-preparative) with a $10 \mu 75 \AA$ Poly(styrene divinylbenzene) stationary phase and an acetonitrile (ACN)/water mobile phase was utilized for all separations. All experiments were performed at ambient temperature with a pressure range of 1000 to 2500 psi. The HPLC program maintained isocratic conditions (75/25 ACN/water) for all separations. Samples were typically injected into the HPLC in DMF/ACN/ $\mathrm{H}_{2} \mathrm{O}$ solution.

Unless otherwise stated, all experiments used optically dilute solutions $(\mathrm{OD}<0.2)$ at room temperature. Fresh samples were prepared for all measurements by dissolving the appropriate analyte in anhydrous DMF. Luminescence solutions were prepared under atmospheric conditions and held in anaerobic $1 \mathrm{~cm}^{2}$ quartz cells (Spectracell, FUV) during interrogation. Absorption spectra were measured with a Shimadzu scanning spectrophotometer (UV-3101PC). Emission spectra were obtained with an Aminco-Bowman luminescence spectrometer (Series 2). The excitation was accomplished with a $150 \mathrm{~W}$ Xe lamp optically coupled to a monochrometer $( \pm 2 \mathrm{~nm})$. The emission was collected at $90^{\circ}$ and passed through a second monochrometer $( \pm 2 \mathrm{~nm})$. Luminescence was measured with a photomultiplier tube $(\mathrm{PMT})$. Radiative quantum yields $\left(\Phi_{\mathrm{r}}\right)$ were measured against $\left[\mathrm{Ru}(\mathrm{bpy})_{3}\right](\mathrm{PF} 6)_{2}$ for which $\Phi_{\mathrm{r}}=$ 0.062 in $\mathrm{CH}_{3} \mathrm{CN}$, accurate to $10 \%,{ }^{2}$ and calculated using the following equation ${ }^{3,4}$

$$
\Phi_{u n k}=\Phi_{s t d}\left(\frac{I_{u n k}}{A_{u n k}}\right)\left(\frac{A_{s t d}}{I_{s t d}}\right)\left(\frac{\eta_{u n k}}{\eta_{s t d}}\right)^{2}
$$

where $u n k$ represents the sample, std represents the standard, $\Phi$ is the radiative quantum yield, $I$ is the integrated emission intensity, $A$ is the absorbance at the excitation wavelength, and $\eta$ is the refractive index of the solvent. For the present work, although the emission spectra of the reference and analyte did not significantly overlap, $\left[\mathrm{Ru}(\mathrm{bpy})_{3}\right](\mathrm{PF} 6)_{2}$ was reasonable selection due to matching excitation wavelength, broad emission band(s), and similar quantum yields. 


\section{$\mathrm{ABI}-\mathrm{NO}_{2}$}

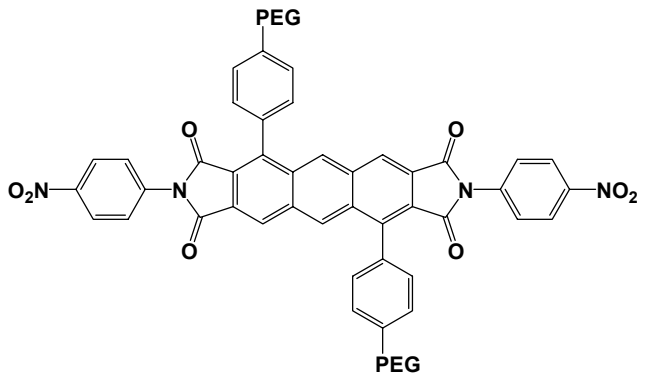

Supporting Figure 1. Structure of N,N'-bis(p-nitrophenyl)-1,5-bis(p-(tetraethyleneglyoloxy)phenyl)anthracene-2,3,6,7-tetracarboxyl bisimide $\left(\mathrm{ABI}-\mathrm{NO}_{2}\right)$.

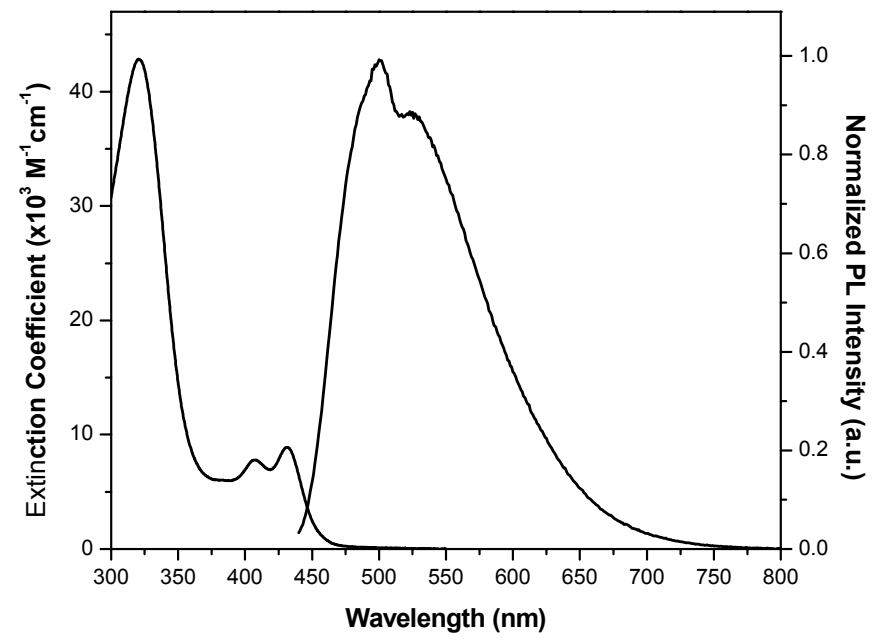

Supporting Figure 2. Absorption (left) and emission (right) spectra of $\mathrm{ABI}-\mathrm{NO}_{2}$ in anhydrous DMF. The luminescence spectrum was collected with $425 \mathrm{~nm}$ excitation.

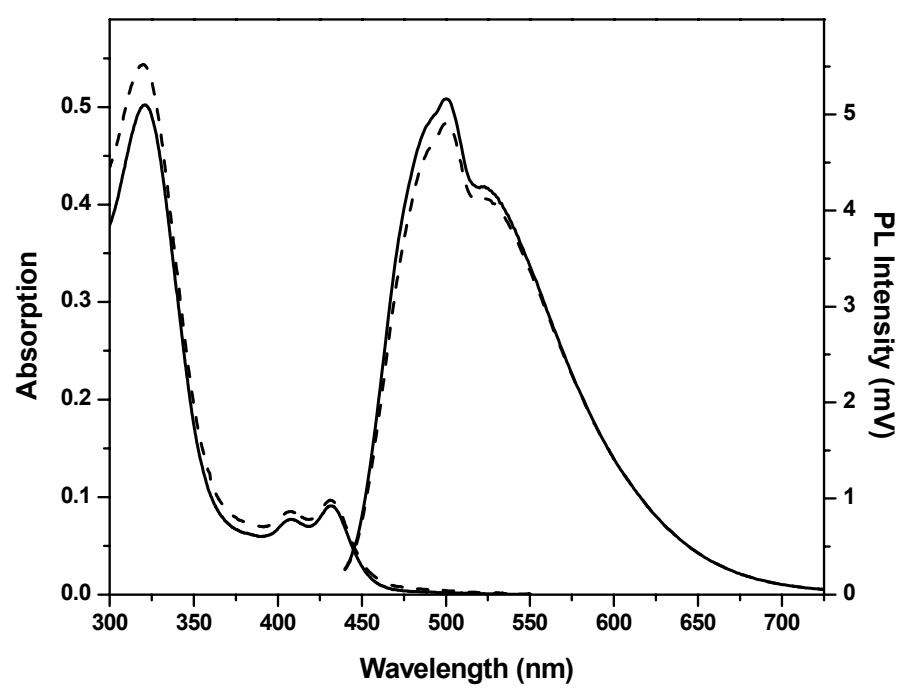

Supporting Figure 3. Absorption (left) and Emission (right) spectra of ABI-NO $\mathrm{N}_{2}$ in anhydrous DMF before (solid lines) and after (dashed lines) 24 hours of continuous irradiation at $425 \mathrm{~nm}$ in the presence of oxygen. 
ABI-NH

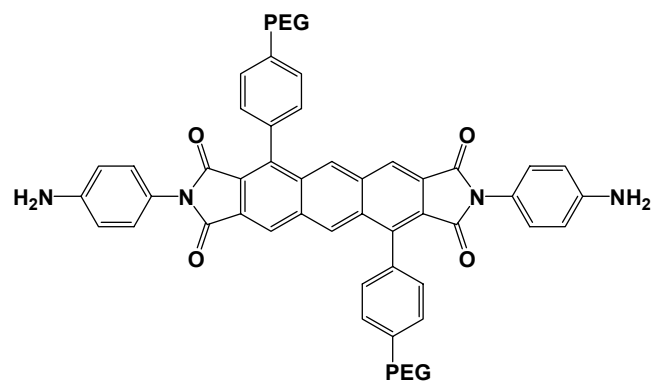

Supporting Figure 4. Structure of N,N'-bis( $p$-aminophenyl)-1,5-bis ( $p$-(tetraethyleneglyoloxy)phenyl)anthracene-2,3,6,7-tetracarboxyl bisimide $\left(\mathrm{ABI}-\mathrm{NH}_{2}\right)$

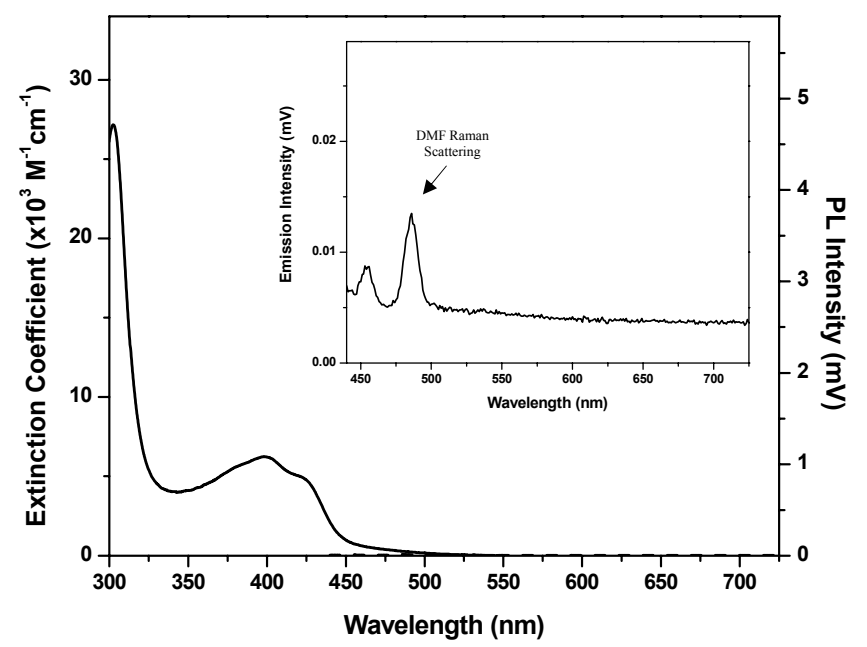

Supporting Figure 5. Absorption (left) and emission (right) spectra of $\mathrm{ABI}-\mathrm{NH}_{2}$ in anhydrous DMF. The luminescence spectrum was collected with $425 \mathrm{~nm}$ excitation. Inset: Magnified view of the emission spectrum.

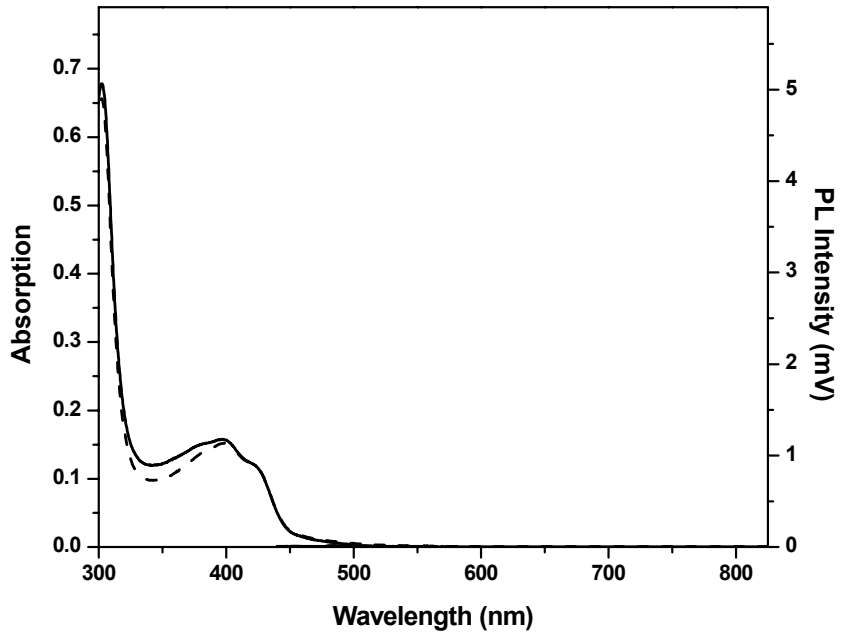

Supporting Figure 6. Absorption (left) and emission (right) spectra of $\mathrm{ABI}-\mathrm{NH}_{2}$ in anhydrous DMF before (solid lines) and after (dashed lines) 24 hours of continuous irradiation at $425 \mathrm{~nm}$ in the presence of oxygen. 


\section{ABI-NH 2 : Titration with trifluoroacetic acid}

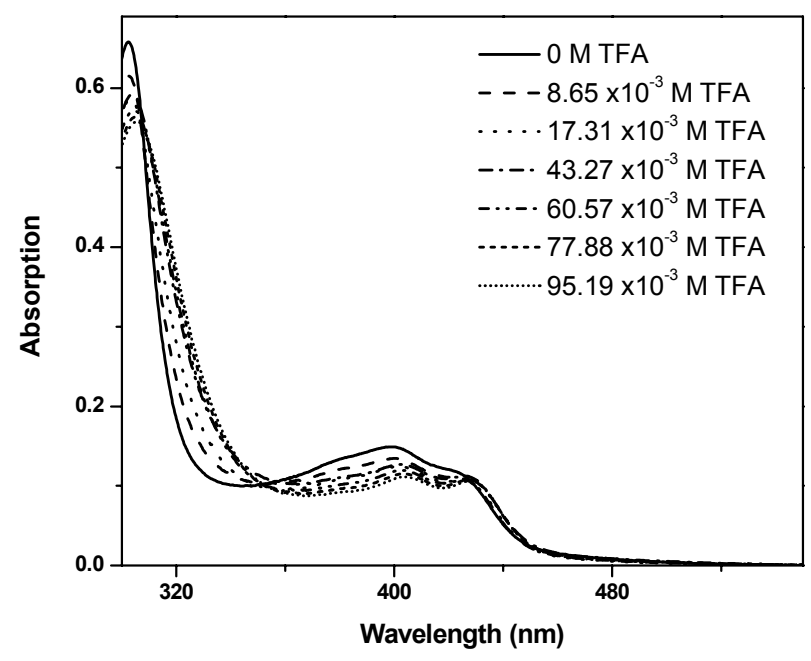

Supporting Figure 7. Absorption spectra of ABI- $\mathrm{NH}_{2}$ in anhydrous DMF during addition of trifluoroacetic acid. The experiment was performed in the presence of oxygen and the acid was diluted with anhydrous DMF and added with a micro syringe.

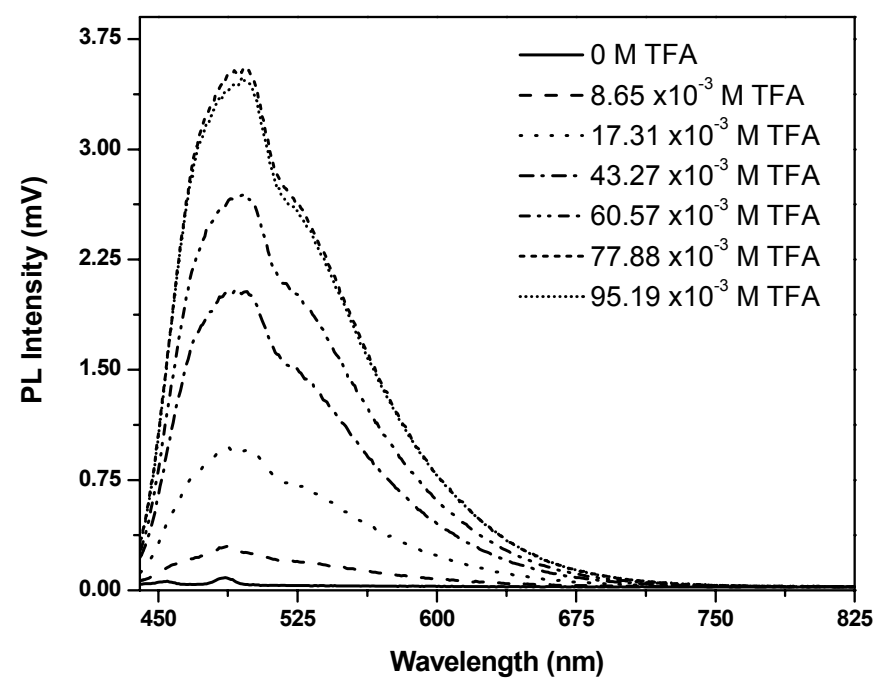

Supporting Figure 8. Emission spectra of ABI-NH $\mathrm{N}_{2}$ in anhydrous DMF during addition of trifluoroacetic acid. The experiment was performed as described above. 
Supporting Information

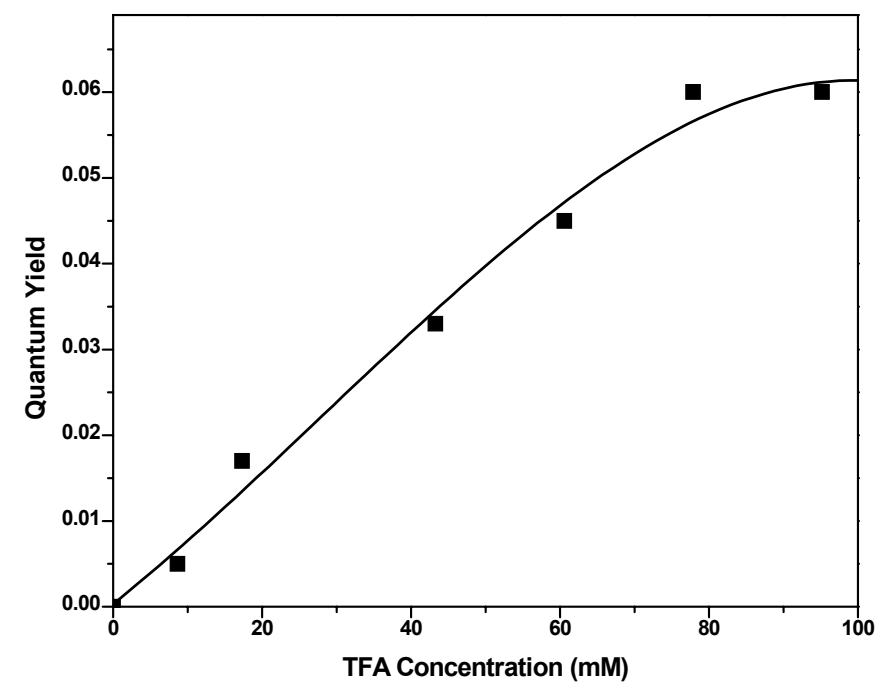

Supporting Figure 9. Titration curve of $\mathrm{ABI}-\mathrm{NH}_{2}$ in anhydrous DMF during addition of trifluoroacetic acid. Quantum yield calculations were performed for each point as a clear isospestic point was not observed.

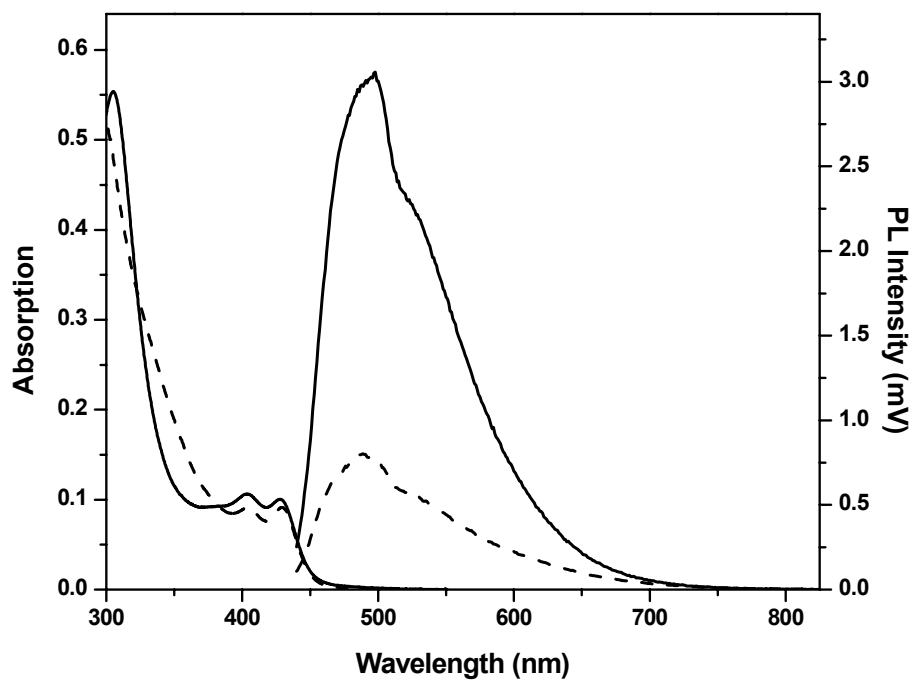

Supporting Figure 10. Absorption (left) and emission (right) spectra of ABI-NH $\mathrm{N}_{2}$ with $95.19 \mathrm{x}$ $10^{-3} \mathrm{M}$ trifluoroacetic acid before (solid lines) and after (dashed lines) 24 hours of continuous irradiation at $425 \mathrm{~nm}$. The measurements were recorded using anhydrous DMF in the presence of oxygen. 
Supporting Information

\section{ABI-NH $:$ Titration with thionyl chloride}
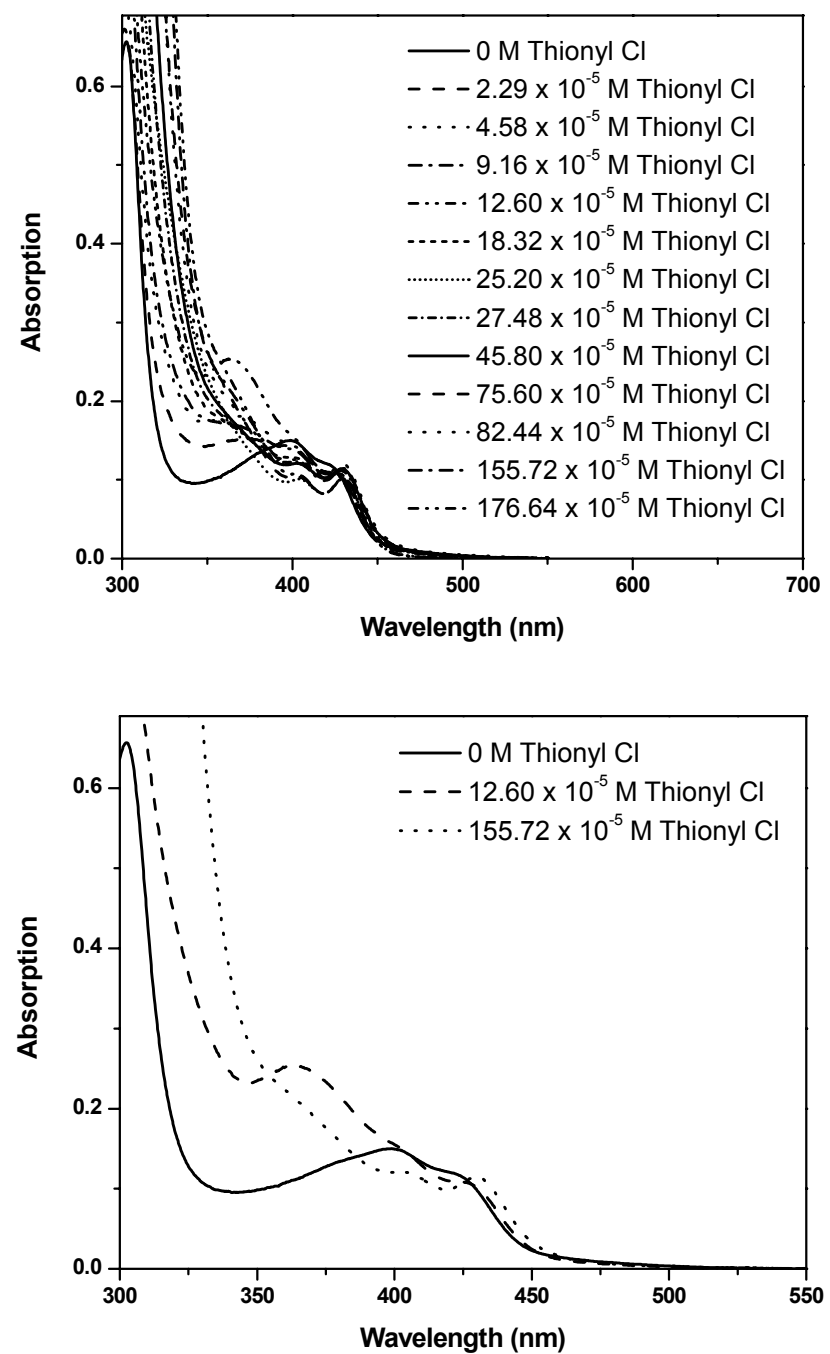

Supporting Figure 11. (a) Absorption spectra of $\mathrm{ABI}-\mathrm{NH}_{2}$ in anhydrous DMF during addition of thionyl chloride. The experiment was performed in the presence of oxygen and the thionyl chloride was diluted with anhydrous DMF and added with a micro syringe. (b) Selected data from Figure 7a showing absorption trends and lack of a clear isospestic point. 
Supporting Information

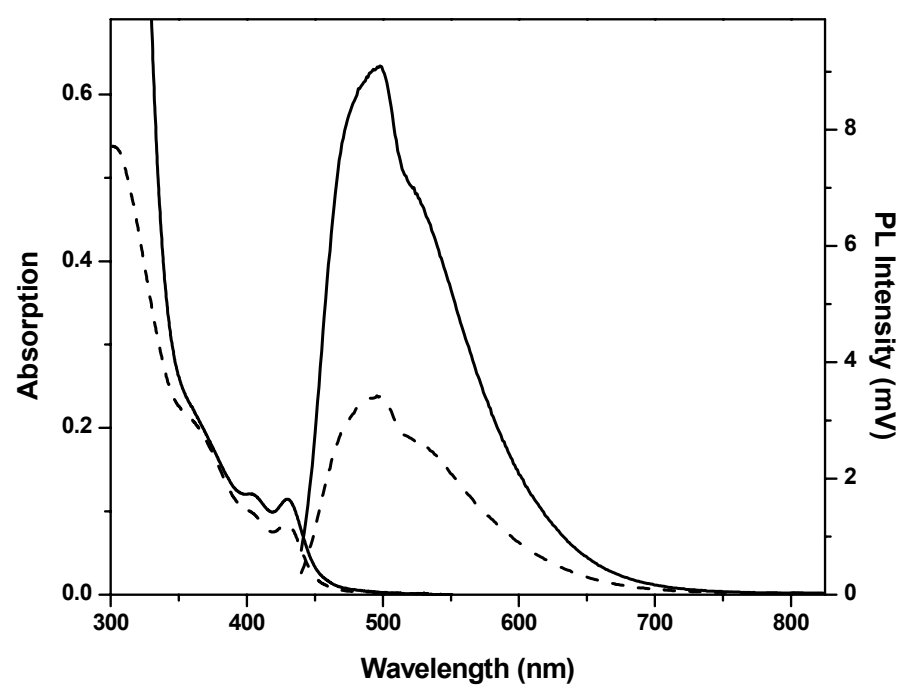

Supporting Figure 12. Absorption (left) and emission (right) spectra of $\mathrm{ABI}-\mathrm{NH}_{2}$ with $176.64 \mathrm{x}$ $10^{-5} \mathrm{M}$ thionyl chloride before (solid lines) and after (dashed lines) 48 hours of continuous irradiation at $425 \mathrm{~nm}$. The measurements were recorded using anhydrous DMF in the presence of oxygen. 
Supporting Information

\section{ABI-NH $\mathrm{N}_{2}$ : Sensing in the Presence of Triethylamine}

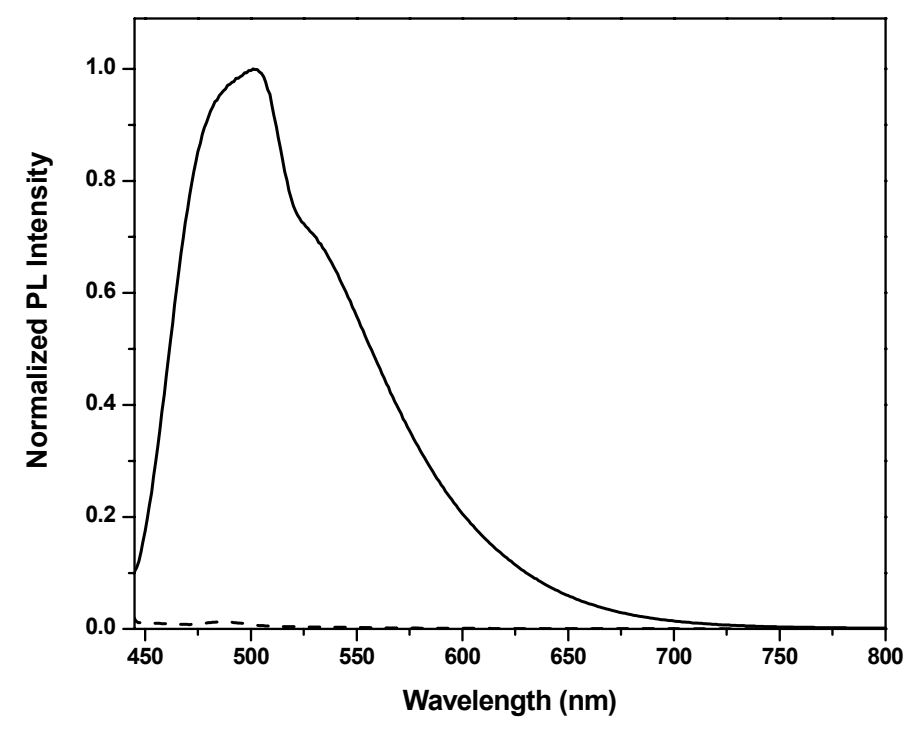

Supporting Figure 13. Emission spectra of $\mathrm{ABI}-\mathrm{NH}_{2}$ with 1 drop triethylamine (dashed line) and with $50 \mu \mathrm{l}$ triethylamine and $5 \mu \mathrm{SOCl}_{2}$ (solid line). The measurements were recorded using anhydrous DMF in the presence of oxygen with $425 \mathrm{~nm}$ excitation.

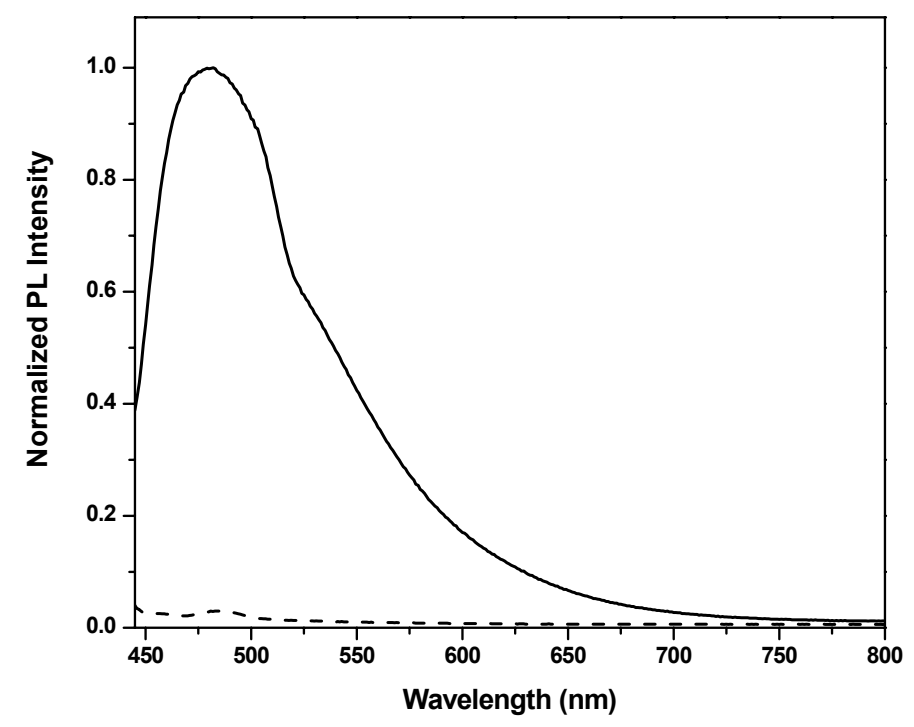

Supporting Figure 14. Emission spectra of $\mathrm{ABI}-\mathrm{NH}_{2}$ with 1 drop triethylamine (dashed line) and with $50 \mu 1$ triethylamine and $5 \mu 1$ acetyl chloride (solid line). The measurements were recorded using anhydrous DMF in the presence of oxygen with $425 \mathrm{~nm}$ excitation. 
Supporting Information

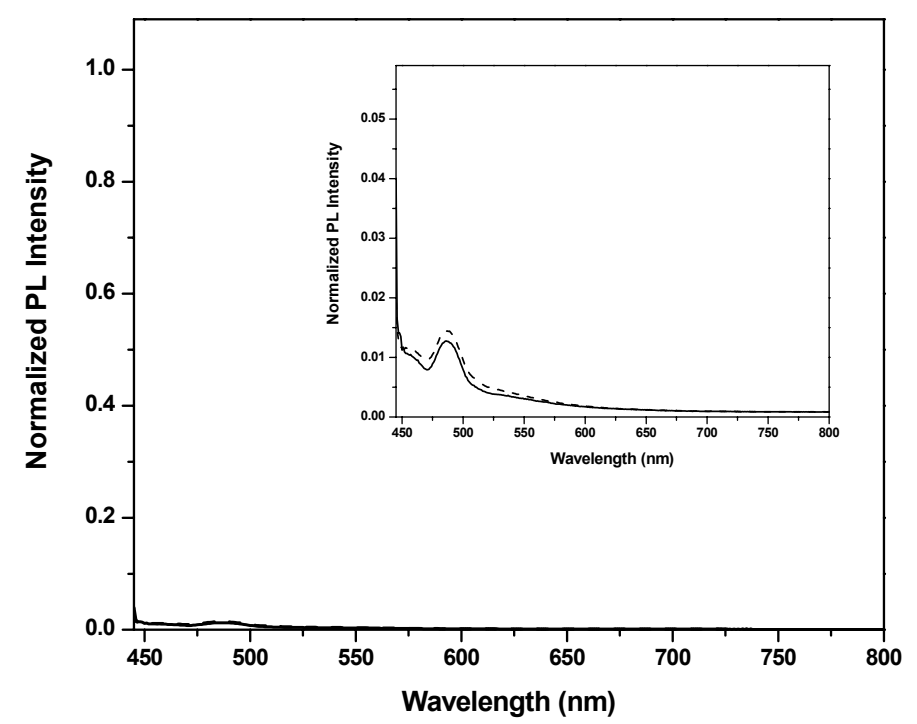

Supporting Figure 15. Emission spectra of $\mathrm{ABI}-\mathrm{NH}_{2}$ with 1 drop triethylamine (dashed line) and with $50 \mu \mathrm{l}$ triethylamine and $5 \mu \mathrm{lTFA}$ (solid line). The measurements were recorded using anhydrous DMF in the presence of oxygen with $425 \mathrm{~nm}$ excitation. Inset: Expanded view.

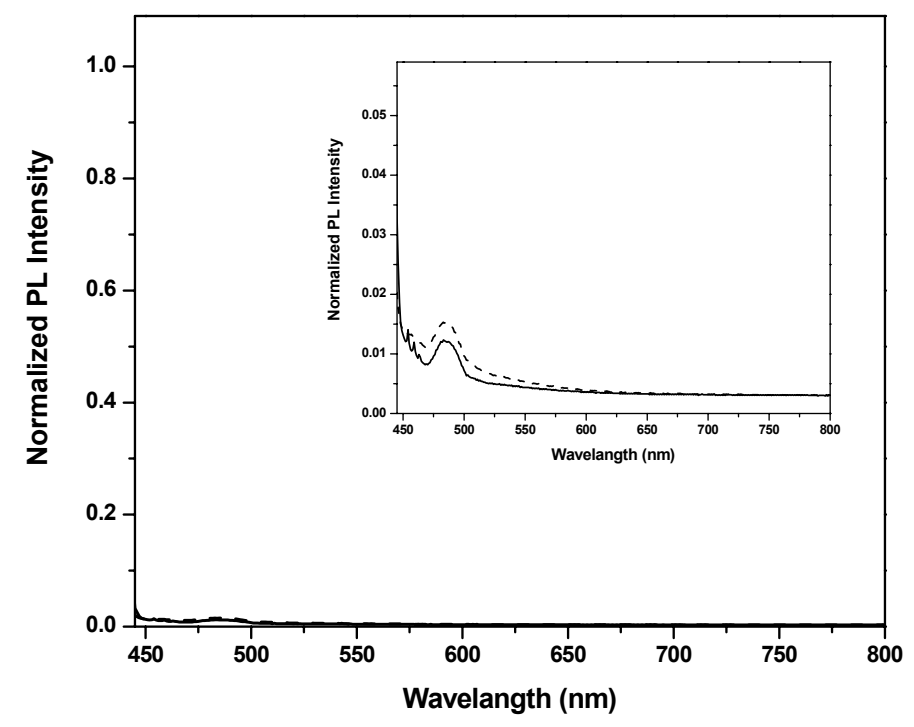

Supporting Figure 16. Emission spectra of $\mathrm{ABI}-\mathrm{NH}_{2}$ with 1 drop triethylamine (dashed line) and with $50 \mu \mathrm{l}$ riethylamine and $5 \mu \mathrm{lconc}$. $\mathrm{HCl}$ (solid line). The measurements were recorded using anhydrous DMF in the presence of oxygen with $425 \mathrm{~nm}$ excitation. Inset: Expanded view. 


\section{ABI-NH2: Reaction with Hexnoyl Chloride}

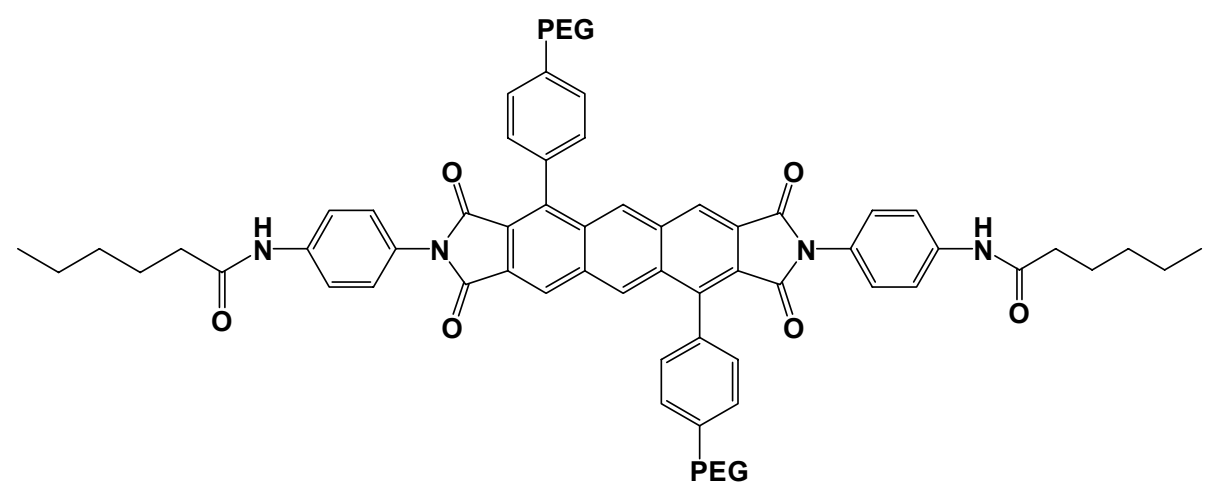

Supporting Figure 17. Structure of N,N'-bis(p-aminophenyl)-1,5-bis(p-(tetraethyleneglyoloxy)phenyl)anthracene-2,3,6,7-tetracarboxyl bisimide after reaction with hexnoyl chloride (the product is ABI-amide). The synthesis was carried out in anhydrous DMF and ABI-amide was purified by flash column chromatography on silica (ethyl acetate to methanol). ${ }^{1} \mathrm{H}$ NMR (300 $\left.\mathrm{MHz} \mathrm{CDCl}_{3}\right): \delta 0.93(\mathrm{t}, 6 \mathrm{H}), 1.30-1.75(\mathrm{~m}, 16 \mathrm{H}), 2.35(\mathrm{t}, 4 \mathrm{H}), 3.38-3.80(\mathrm{~m}, 22 \mathrm{H}), 3.95(\mathrm{t}, 4 \mathrm{H})$, $4.28(\mathrm{t}, 4 \mathrm{H}), 7.15(\mathrm{~d}, 4 \mathrm{H}), 7.39(\mathrm{~s}, 2 \mathrm{H}), 7.43(\mathrm{~m}, 8 \mathrm{H}), 7.25(\mathrm{~d}, 4 \mathrm{H}), 8.53(\mathrm{~s}, 2 \mathrm{H}), 8.70(\mathrm{~s}, 2 \mathrm{H})$.

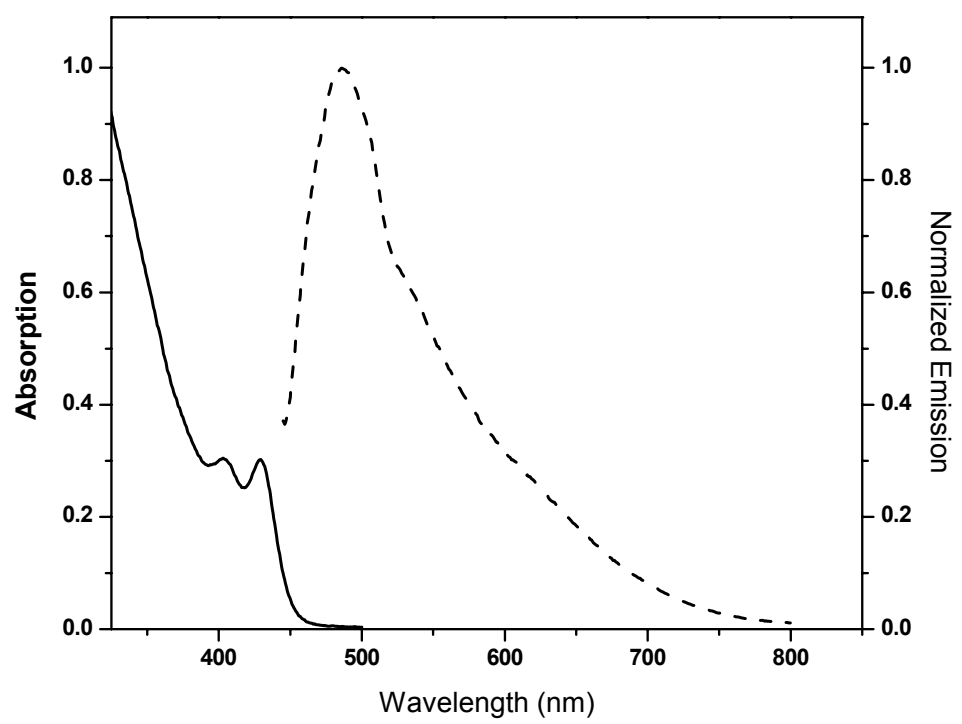

Supporting Figure 18. Absorption (left) and emission (right) spectra of ABI-amide after purification by silica column. The measurements were recorded using anhydrous DMF in the presence of oxygen with $425 \mathrm{~nm}$ excitation. 


\section{References}

(1) (a) Roderick, W. R. J. Am. Chem. Soc. 1957, 79(7), 1710. (b) Szabó, C.; Mabley, J. G.; Moeller, S. M..; Shimanovich, R.; Pacher, P.; Virág, L.; Soriano, F. G.; Van Duzer, J. H.; Williams, W.; Salzman, A. L.; Groves, J. T. Molecular Medicine, 2002, 8(10), 571.

(2) Casper, J. V.; Meyer, T. J. J. Am. Chem. Soc. 1983, 105, 5583.

(3) Damrauer, N. H.; Boussie, T. R.; Devenney, M.; McCusker, J. K. J. Am. Chem. Soc. 1997, $119,8253$.

(4) Demas, J. N.; Crosby, G. A. J. Phys. Chem. 1971, 75, 991. 